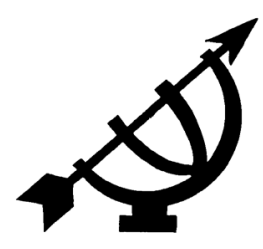

\title{
Embodied freedom
}

\author{
H.G. Geertsema \\ Emeritus Professor \\ Dooyeweerd-chair \\ Department of Philosophy \\ Vrije Universiteit \\ AMSTERDAM \\ E-mail: hgg@bos.nl
}

\section{Abstract \\ Embodied freedom}

In this article I explore the relationship between freedom and embodiment. Firstly I argue that freedom is an essential part of our being human, whatever science might say, and should be understood as the possibility to be ourselves. I propose an understanding that starts from the perspective of the second person. In the second part I analyse the writing of a scientific article as a case study of the experience of freedom in a concrete practice. I show how normative elements are a necessary part of such a practice. In the third part I argue that the "free agent" is in fact the concrete person who acts and thinks. I also discuss the place of causation. In the final part I elaborate on the view of the person, as understood from a second person perspective, and on the meaning of freedom, taking my starting point in the biblical understanding.

\section{Opsomming}

\section{Vrijheid en lichamelijkheid}

In dit artikel onderzoek ik de relatie tussen vrijheid en lichamelijkheid. In de eerste plaats probeer ik te laten zien dat vrijheid essentieel tot ons menszijn behoort, wat er ook door de wetenschap wordt beweerd, en moet worden opgevat als de mogelijkheid ons zelf te zijn. Ik stel voor vrijheid te verstaan vanuit het perspectief van de tweede persoon. In het tweede deel analyseer ik het schrijven van een wetenschappelijk artikel als een "case study" van de ervaring van vrijheid in een concrete praktijk. Ik laat zien hoe normatieve elementen een noodzakelijk onderdeel vormen van zo'n praktijk. In het derde deel probeer ik te laten zien dat het de concrete persoon is die handelt en 
denkt. Ik bespreek ook de plaats van causale relaties. In het laatste deel ga ik uitvoeriger in op de opvatting van "person" vanuit het perspectief van de tweede persoon en op de betekenis van vrijheid, waarbij ik mijn uitgangspunt neem in het bijbelse verstaan.

\section{Introduction}

In her book Metaphor and its moorings M. Elaine Botha (2007) attempts to interpret the idea of embodied knowledge in terms of Dooyeweerdian philosophy. In this article, written to honour her, I will do more or less the same in relation to the idea of embodied freedom. This topic would actually also require a book rather than an article. It should be clear, therefore, that within the confines of this article I can give only the general outlines of a view that actually requires a much more detailed elaboration and refinement both in terms of analysis and argument. I start with a first indication of what I understand by freedom and how it relates to our view of the human person. In the second part I offer a case study to elaborate on the situatedness and complexity of freedom. Next, I deal with some topics related to scientific discussions. Finally, I come back to the meaning of freedom for our life as humans. The last two parts discuss the embodied nature of freedom more explicitly. 1

\section{Freedom as response}

In this part I will give a first indication of what I understand by freedom. I argue that freedom, contrary to what science may claim, cannot be dismissed, because it is an essential part of our selfunderstanding, and I try to show that the understanding of freedom exclusively in terms of free will or free choice does not do justice to our experience. I claim that freedom should be understood as the possibility to be ourselves. In the second section I add to the understanding of ourselves, in terms of a first and a third person perspective, the idea of the homo respondens and the priority of the perspective of the second person.

\subsection{Freedom as the possibility to be ourselves}

For many scientists the idea of freedom has become problematic. Especially the neurosciences have shown that behaviour which is alleged to be an expression of human freedom is deeply dependent

1 l'd like to thank Gerben Groenewoud for improving my English. 
upon physical processes in the brain. Some experiments, like those of Benjamin Libet and Grey Walter (Libet, 2004:54; Dennett, 1995: 174; Den Boer, 2003:245, 247), even indicate that conscious awareness of decision making is preceded, however shortly, by activity in the brain. The situation in the social sciences may be different, yet, here too human behaviour often is explained in terms of cause and effect without any reference to freedom and responsibility. If, as a result, the discussion is about the degree to which nature or nurture determines human conduct, in either case, freedom is left out of the picture. Some scientists and philosophers draw the conclusion that freedom is an illusion. Others are more careful. Yet, it is clear that, however popular the notion of individual freedom may have become as the motivation behind many people's actual behaviour, in the field of science and philosophy it raises serious questions.

This apparent tension actually points to a more specific question, namely what the relationship is between theoretical or scientific explanation of human conduct and our concrete experience of the same. It will not be difficult to show that many examples of behaviour that are experienced as an expression of freedom are actually deeply influenced by genetic and social factors. For some philosophers this is not a problem. "Compatibilism", as the view which attempts to combine the notion of freedom with an explanation in terms of cause and effect is called, is rather popular among them. The problem of this approach is that freedom seems to be just a feeling and, therefore, could easily just be an illusion. At the same time, if some behaviour that is claimed to be a true expression of freedom is actually deeply influenced by social and genetic factors, there may be some truth to this conclusion. On the other hand, the main argument for the defence of freedom as not simply an illusion is our self-experience, both in an individual and in a social sense. As an individual I experience myself as a free agent, not just as an element in a chain of cause and effect. For our social life it is a basic assumption that people can be held responsible for what they are doing. This applies not only to our legal system, but also to family life, employment in a business or school, sports organisations, et cetera. In some sense it is essential to our actual self-understanding that we are free agents, that our conduct cannot be fully explained in terms of cause and effect, either of nature or nurture. I believe that this is indeed a valid argument. Whatever scientific explanation(s) can be given of our concrete behaviour, there remains a "rest" that escapes this explanation and which is essential to our being human. 
Scientific explanations, both in terms of nature and nurture, are important for our understanding of human conduct, yet they are not exhaustive. Sometimes this is phrased in terms of the distinction between a third and a first person perspective. The third person perspective applies to science and its method of objectification. The first person perspective characterises our subjective experience. Thomas Nagel (1986) has argued convincingly that the latter perspective cannot be reduced to the former. The strongest argument may be the fact of scientific explanations itself. Implicit in scientific explanations is their claim to be meaningful and (potentially) true. As such they are part of the first person perspective. Therefore, scientific explanations are human activities that cannot be fully explained in terms of cause and effect, in terms of nature or nurture. If this were the case, their claim of truth would lose its meaning. The third person perspective of scientific objectivity presupposes the first person perspective of subjective experience. As a corollary we can say that scientific explanation itself somehow implies the validity of human freedom and responsibility. In part three and four I will elaborate on this point.

So the main argument for human freedom is indeed our self-experience. In this light it is remarkable that freedom is often especially connected with free will or free choice. Freedom is understood as the freedom to choose between alternatives (Nagel, 1986:116, 121; Labooy, 2007:146). I do not deny that this indeed is an essential element of freedom. Yet, I wonder whether it is the very essence of our freedom as it characterises our being human. Is this actually the main point in our experience of freedom? Do I feel free, especially when I am in the position to choose between alternatives? It may even be the case that I feel forced to make a choice. Again, I do not deny that the possibility to make a choice is an essential part of freedom, yet, I will argue that our experience of freedom goes beyond the possibility of making choices.

To get a first impression of this wider meaning of freedom, it may be helpful to refer to two distinct experiences, the first of which refers more to freedom in the classical Greek understanding and the second to the emphasis in modern thought. I can feel free when I am at home, because there I can be myself, I am accepted as I am, I do not have to prove myself, and I do not have to adjust to conditions that are alien to me, like a slave in a foreign country. Yet, being at home also implies that I accept the situation of "home" as given. Therefore, the experience of freedom can also be connected with leaving home and living on my own, creating a space for myself, 
making my own home. The modern understanding of freedom is especially connected with making the world as we want it to be, whilst the traditional sense of freedom is more connected with feeling at home in the world as it is given. Although the emphasis of the traditional understanding is very different from the modern one, both kinds of experience, I believe, are universal. The point I want to make is that these observations suggest that freedom relates to the possibility to be ourselves. The first approach concerns our experience of freedom in a given situation, because it suits us as we are. The second approach relates to the experience of freedom in relation to what we would like to do. The two elements actually need each other, because of the beings we humans are. Freedom in the first sense I will call "receptive freedom", freedom in the second sense will be referred to as "creative freedom". Either way, the experience of freedom appears to be more than just having a free will or the freedom to make our own choices.

\subsection{Freedom and our understanding of the self}

"Freedom relates to the possibility to be ourselves." This relation makes our understanding of freedom dependent on the way we understand ourselves. This dependence was already clear in the difference in emphasis between classical Greek and modern thought. To give a few more illustrations, Immanuel Kant connects freedom with rationality, because, for him, inclinations and natural affections do not characterise our typical human nature, while the rational autonomy of our will does. Moreland and Rae (2000) relate freedom to a soul substance over against the material body, because for them the essence of our being human is to be found there. Nagel (1986) discusses freedom in terms of the tension between subjectivity and objectivity, since, according to him, our humanness is characterised at the same time by its aiming at the objectivity of the third person perspective (the view from nowhere) and its being bound to the subjectivity of our first person perspective.

In different ways Nagel as well as Moreland and Rae relate freedom to an absolute new beginning. For Nagel freedom in an ideal sense should be absolute, as if the choice between alternatives is made from nowhere. Of course, he realises that this is not possible. Choices are always made in concrete situations and are, therefore, conditioned. No choice is completely free. Moreland and Rae (2000: $125,126)$ speak of an absolute source or an absolute originating source. They want to show the contrast between agent causation and event causation. The latter always functions within a chain of 
events. The former starts something new and cannot be explained on the basis of what went before. The activities of human agents cannot be reduced to natural events within a chain of cause and effect. The distinction is important, but to characterise human freedom or even free will as an absolute (originating) source seems unwarranted. It suggests that it comes from the "nowhere" that Nagel refers to, while every human choice is actually conditioned and situated. In what follows, I will propose another approach of freedom in terms of homo respondens, the human person as an answering being.

Somehow Nagel as well as Moreland and Rae understand freedom in terms of the first and the third person perspective. Nagel argues that the free will cannot be fully understood because it finds its place in the tension between the two perspectives. It seems that we have more freedom if we can look at our situation from a greater distance. Yet, taking an objective stance also alienates us from the same concrete situation, and therefore becomes a hindrance to make a choice in that situation (Nagel, 1986:117). Moreland and Rae argue for the connection between free will and a soul substance. Most of the language they use can be understood from the first person perspective, as self-experience of being human provides the foundation for their view of the free agent. Yet, the very notion of substance as a characterisation of the human person betrays a third person perspective. The notion of "substance" is unmistakably a theoretical one, because it cannot be directly related to our self-experience. I do not experience myself as a soul substance. Besides, it contains a tension, because at the same time it is used to explain our unique individuality as a free agent and our essence as a human being which we share with all other humans. Over against Nagel and Moreland and Rae I propose that we start with the perspective of the second person. I am addressed before I answer. My being free is positioned in this answering. In sections 3.2 and 3.3 and in part 5 I will discuss the perspective of the second person more elaborately.

\section{A case study}

To gain some more understanding of freedom I will discuss one specific practice albeit only in general terms. Our experience of freedom is extremely diverse, so I have to make a choice. I made the contention above that science itself presupposes freedom. I will now attempt to substantiate that claim by taking for a case study the writing of a scientific article. One may even think of a paper which tries to argue that there is no free will, that the neurophysiologic 
processes in our brain are all there is to determine what we do. First I will give a general description and analysis of the practice and what is presupposed in it.2 Then I elaborate on this analysis in terms of the perspective of the third, the first and the second person. In the third place I discuss how a worldview is involved. I end with a short conclusion. In my analysis the focus is on what I have called creative freedom. Yet receptive freedom is implied throughout.

\subsection{Description and analysis of a practice}

No one can write a scientific article without sufficient education, one which starts with learning a language at home and in primary school. It continues in secondary school and university. A specific field of study is chosen and academic abilities are developed. For the article itself research is done either by doing experiments or by reading the relevant literature, or by doing both. However, experimenting and reading are in itself not sufficient. The experiments and literature need to be analysed and conclusions must be drawn. In all these activities specific norms must be satisfied. Experiments and analysis need to be conducted properly. If they are done improperly, the result will not be acceptable. Next follows the phase of writing. New criteria apply, like consistency of argumentation and clarity of composition. In all these respects the author has to show competence and the result will be assessed according to criteria of excellence. Some criteria may be specific for the journal to which the article will be submitted, like the length of the article and the format and number of footnotes or endnotes.

In this long process that preceded the writing of the specific article the author has probably experienced both freedom and the lack of it. Maybe at first he did not like to go to school at all and was forced to do so. However, at some point he should have enjoyed at least parts of his education. Either way, the possibilities he now has as a writer would not be there without this extended education. During the writing of the article, many choices have been made. Some may have been made unwillingly, like following the restraining conditions of the editor of the journal. Yet, even these conditions may ultimately have appeared to be a challenge that led to a result he is now really content with. "This is what I wanted to say. And I have said it in a way that completely satisfies me." Such a statement, I contend,

2 My analysis shows similarities to the description of a social practice by Maclntyre (1981:175) and to its reinterpretation as "normative practice" within reformational philosophy (Jochemsen, 2006). 
gives expression to a true experience of freedom. Ultimately the author has expressed his ideas and perhaps even something of himself in a way that fully satisfies him. He appears to be himself in the work he has achieved. Of course, there may be limitations to his achievement, but it illustrates what I believe freedom is about.

We will look at the above-described more abstractly now. I will make use of the theory of modal aspects of so-called reformational philosophy to do so. This theory contends that we can distinguish in reality about fifteen different basic aspects each with its own laws. The aspects can roughly be indicated as follows: numerical, spatial, movement, physical, biotic, psychic (referring to perception and the senses), logical, historical or formative, lingual, social, economic, juridical, aesthetic, ethical, faith or trust. The theory states that these aspects are irreducible to one another in terms of concepts and laws. This means that the theory defends both epistemological and ontological non-reductionism, assuming that laws refer to regularities within reality itself. At the same time the theory accounts for the coherence between the aspects in terms of retrocipations and anticipations: elements within each aspect refer back to earlier ones and forward to later ones in the scheme. I will not try to show how in the case of writing a scientific article all aspects have a necessary function, although this would not be hard to do. I want to show, firstly, that different aspects have a different kind of function and yet are integrated in a specific kind of unity, even if the writing is described as an event (third person perspective); secondly that the real unity of this event can only be understood in terms of an action of an agent (first person perspective); thirdly that both perspectives can be integrated in terms of an action by an agent called for and made possible by a specific situation (second person perspective).

When we take the event of writing in a limited sense, it is clear that the body with its physical and biotic aspects is involved. This holds for the external bodily movements of handling a personal computer as much as for the internal processes that occur within the brain. Yet, to understand the nature of the event, these aspects are clearly not sufficient. In my earlier depiction it appeared that learning the proper language and methodology of the field of study were crucial for being able to write the article. In terms of the different aspects it is the logical and lingual aspects that indicate the typical nature of the event of writing and the article as its result. However, we need at least one more aspect to grasp the nature of the event, namely the formative. Writing the article requires creativity. It cannot be done by just following the rules of logic and language. At the same time this 
creative freedom is bound to make a proper use of the rules of language and logic. The first group of aspects, like the physical and biotic - and I could add the psychic - form a necessary foundation for those aspects that characterise it in its typical nature. There is also a third group of aspects, which we could call the conditional, e.g. the economic, the juridical, and the ethical. Writing a scientific article requires that the necessary economic means are available. There is also the issue of copyrights that needs to be dealt with. Moreover, if the author is married and has children, it is clear that the way he/she spends his time will affect the other members of the family. There is also the ethical relation with colleagues in the field, and whether or not they are properly acknowledged for their contributions.

All these aspects are part of the event of writing a scientific article. Some of these aspects - most of them, as a matter of fact - have a normative dimension. Certain rules of logic and language, in general the accepted criteria of the field, need to be acknowledged. The economic, juridical, and ethical aspects also imply certain norms or values that should be respected. The physical, biotic and psychic aspects that in themselves may not have a normative dimension are integrated, though, in the event as a whole and as such can function in a proper or improper way. Writing with the hand or typing on a keyboard is not just a physical action; it is guided by the process of writing with its necessary rules of language and logic. The same should be acknowledged for the processes within the brain. They are not just physical movements. They are controlled by the event as a whole in its typical nature, just as the hardware of a computer in its actual functioning is ruled by the software that is applied for a specific purpose. What goes on within the brain is not an isolated process, it is integrated within the event of writing, within the overall life of the author and the long learning process that makes this writing possible. In the same way as the external conditions of the body may at some point make the act of writing impossible, it may happen with the internal processes of the brain. If the hardware of the computer is broken, the software cannot function anymore, and the use of the computer for writing is made impossible. However, that does not make the software explainable in terms of the hardware, or even reducible to it. Let alone that the actual use of the computer for a specific purpose could be explained in terms of the hardware. The proper function of the hardware is a necessary condition for any user to accomplish what he/she has in mind. It does not define the latter. The same is true for the neurophysiologic 
processes within the brain in relation to the act of thinking. The former are a necessary condition, not a fully determining cause.

\subsection{Different perspectives}

Until now I have analysed the writing of an article in terms of the different aspects of an event. In other words, my analysis so far has taken on a third person perspective. I now want to move on to the first person perspective. Writing an article is not just an event, it is the action of an agent. A scientific article does not appear just because some physical or even lingual and logical processes are at work. The difference between an action and an event is that an action implies an actor or agent, while an event as such does not. Writing an article implies a writer. In my first description the author was implied all the time: someone was educated, someone was trained in a specific field and someone did the writing. Hence, the first person perspective was tacitly implied all along. It is the writer that applies the rules of language and logic. It is the writer that succeeds in being creative. It is the writer that moves his/her hands and body to hit the right keys on the keyboard to produce the text he/she has in mind. Even though the movement of the hands and fingers may be as automatical as the applying of the rules of logic and language, it is still the writer that experiences all of these as his/her activities. They are part of the action by which he/she wants to achieve the article. In all these he/she experiences the freedom to do what he/she wants to do or maybe also what he/she feels obliged to do. He/She may also have to overcome constraints. Maybe at the end the constraints are too strong.

The processes within the brain are in a basic sense not very different. They too are part of the overall activity of the writer, even if he/she has no conscious control over these processes as such. $\mathrm{He} / \mathrm{She}$ cannot change these processes in a direct sense as he/she can do with the movement of his/her hands. Yet, moving his/her hands is also the result of a long learning process. These movements are not consciously chosen all the time. They are part of the overall free activity of writing which is chosen, this writing itself being part of a wider practice and of the life of the author. It is not an isolated action, but it is situated within a concrete practice. The actual functioning of the processes of the brain is part of the same overall activity and cannot be understood apart from it. They too have been shaped during the learning process of the author. They function within his/her life as a necessary condition, but not as a fully determining process. If the activity of writing the article is reduced to 
the processes within the brain, it cannot be properly understood anymore. Not only are the aspects that characterise the writing of an article being ignored, like the logical, the lingual and the creative, each with its normative dimension, but writing an article with a claim of truth looses its meaning when there is no author who makes this claim. Processes, even in a logical-lingual sense, do not make a claim of truth. Here a first person perspective is necessary - the author with his/her aims and purposes within a concrete practice. This first person perspective cannot be analysed in the same way as the processes within the brain, it cannot be understood in terms of a logical analysis or an argument expressed in language either. These analyses refer to aspects of the concrete action of which the person is the agent. Within the action they are integrated into a unity. This unity itself cannot be understood apart from the agent that is performing the action. ${ }^{3}$

To fully understand the writing of an article we cannot limit ourselves to the third person perspective. We also need the perspective of the first person, even where this perspective escapes scientific analysis. Yet, the third and first person perspectives together are still not sufficient. In this way the relational character of the activity is not accounted for. The first person perspective looks at the act of writing as an activity of the writer. It also considers the situation in which the writing takes place from the perspective of the author. As such it does show how this activity relates to the situation in which it is performed. We can also look at the act of writing from the perspective of the situation. This situation is not only a condition for the activity of the writing. In a way it also calls for the act of writing as a response to it. The author responds to the state of the research in the field and to the people that have written about the subject, whether they are explicitly mentioned or not. It may be that reading and analysing the relevant literature almost by itself led to a research question that asked to be addressed. In this case the writing of the article clearly has the nature of a response called for by the situation. It may be that the topic was chosen out of a long cherished interest and that the literature was only collected afterwards. Even in this case the article will respond to the given situation. To be meaningful the topic cannot be created arbitrarily by the author. He/She

3 The necessary relationship between an action and an agent is recently explored anew within philosophy of language as speech-act theory (Austin, 1975; Searle, 1969) which in turn has stimulated a new attention for the author of a text in hermeneutical theory (Wolterstorff, 1995; Vanhoozer, 1998). 
responds to what there is, both in terms of the relevant literature and the people who have written about the topic.

In a more abstract sense we can say that the author also responds, implicitly, to the norms of the various aspects that are involved, like the logical, the lingual, the economic and the ethical. Like the situation in which the writing is performed, these aspects too make the writing possible and ask for a response from the author. Both the situation and these aspects are given before the writing can take place. They are a condition for its possibility although they do not fully determine the act of writing. They ask for a response, the activity of the writing itself, in the same way as the rules of chess make playing a chess game possible, but are not themselves the playing of the game. For the latter a player is necessary, actually in most cases two. The author, like the chess player, responds to a situation and the rules that are implied when he/she writes the article. In a way we can integrate the first person perspective with the third person perspective from the second person perspective. The aspects, which we can analyse scientifically, are given like the rules that make the game possible. This we have called the third person perspective. The situation which calls for a response from the agent is also given. This we call the second person perspective. Then there is the agent him-/herself, who responds to the situation on the basis of the different aspects that make his/her response possible. The structures of the situation and of the response can, therefore, be called answering structures. They make the activity possible without fully determining it. In this way freedom is essential to any activity. It is made possible by a situation, it may be conditioned by it in many ways, but as an activity, it always contains the element of response. Without this element it would no longer be a human act.

\subsection{The ultimate horizon}

There is still another element in the second person perspective that needs to be mentioned. Maybe the writing of the article was not a free choice, but an assignment given by someone higher in the hierarchy. Even then there is an element of choice - the assignment is accepted or not. The author remains responsible, not just for the content, but also for the act of writing as such, even if the writing was an act of obedience. Being obedient does not take away our responsibility, although it does qualify it. As a responsible activity it cannot be totally without freedom. Obedience should never be totally blind. Obeying a command does not take away the responsibility for what we do. If the command is completely unacceptable we can 
refuse to obey, whatever the consequences. I make this detour as a preparation for the final element in the second person perspective that I want to mention.

The distinction that I just pointed out, concerns the difference between what could be called an answer to a question which as a challenge is implied within a situation, and an answer to a spoken call or promise that is addressed to us. Our response to a situation is not the same as our response to other people. This distinction becomes important when we look at the way we ultimately understand ourselves and the world. So far I pointed out how we respond in a concrete situation in relation to its possibilities, its limitations and its challenges. However, each situation is part of the world at large. In our response within that concrete situation somehow we do respond to that world at large. This is true as much for the writing of a scientific article as for the political views we defend. We can always ask what our response means in relation to our humanness, the way we understand ourselves and our place in the world. It is part of our being human that implicitly or consciously we have a view about the reality in which we live. How did this reality originate?, Where does it go?, What is its ultimate meaning?, What is our place in the midst of it?, and What ultimately renders my activity of writing this article meaningful at all? As humans we cannot avoid these questions. If we do not consciously reflect on them an answer will show in our actual conduct, probably in line with what is common in the culture we are part of.

The philosopher Martin Heidegger considered the question of the meaning of being the most basic that can be asked. Sometimes he characterised his philosophical journey simply as an attempt to ask this question in the right way. At the same time he rejected the answer of the Christian (and Jewish and Islamic) faith to this question in terms of the world being God's creation. According to him in this way an answer is given before the question is really asked (Heidegger, 1997:33). It is indeed a characteristic of the Christian (and Jewish and Islamic) faith that the ultimate horizon of our existence cannot be phrased in terms of a question to which we should find an answer; this ultimate horizon should rather be viewed in terms of a word that is addressed to us. For Heidegger the world at large is a given and as such it challenges us to ask the question about the meaning of being as if "being" is merely a "situation". Christianity (together with Judaism and Islam) implies that as humans we respond to a Person who has revealed himself as the Creator in the world as his creation. The "Origin" of the world has 
even addressed us by revealing Himself in the words He has spoken by his messengers (Heb. 1:1) and as such is asking for a response. Actually, the very nature of created reality can be characterised as a response to God's (creative) Word (Gen. 1). God calls into being and this call consists of two elements, namely a command to exist and a promise that it will be good (Geertsema, 2008:239). When we apply these two elements to our own being we can distinguish between two basic components in being human: calling and responsibility in relation to the command, and desire and expectation in relation to the promise. These two elements characterise us as human beings. Being created can be characterised as answering to the promise-command to be, God's creative Word. This we share with all other creatures. Here we find the deepest reason why the second person perspective has priority. Created reality is and precisely as such it is a response to God's call to be. However, to be created human entails something special. As humans we are answering in our relation to God our Creator, answering through our very being, and answering in responsibility and expectation. In this relationship we are called to be ourselves. This call is a promise at the same time. In our response to this call we reach the deepest level of freedom.

In connection with the concrete situation of writing an article, I made the distinction between the perspective of the third, the first and the second person. The second person perspective cannot be without that of the first. Being addressed and responding necessarily go together. I related the third person perspective to the scientific analysis of the diverse aspects of the situation in which we respond. Can we distinguish the same three perspectives within the relationship between us as creatures and the Creator? The second and the first person perspective are clearly there. As creatures we respond to a promise-command to be. What about the third person perspective? Can we analyse aspects of this relationship in a theoretical or scientific way? It is clear that we can reflect on this relationship. This is, however, not sufficient to speak of a third person perspective. Characteristic of a third person perspective is that we take some distance in our analysis. We abstract one aspect from a totality, but we also abstract from our personal involvement. Both are the result of what characterises the third person perspective: abstract conceptual and methodical analysis. It appears to be part of the relationship between creature and Creator that neither kind of abstraction is possible. The relationship between creature and Creator is all encompassing. So we cannot abstract it from something else. All analysis itself is possible only on the basis of this rela- 
tionship. So there is no possibility in any sense to take an objectifying stance by means of concepts and method. At the same time, we are immediately involved in this relationship. Our very being is involved. So there is no possibility to take a distance from it in the sense of not being directly involved. For this reason, I believe, the relationship between creature and Creator escapes theoretical analysis. Ultimately our being as a response to the promise-command to be of the Creator remains a mystery. We are invited to live and experience this mystery. We can reflect upon it, but we cannot fathom it, let alone theoretically grasp it. Ultimately, the same must apply to the freedom involved in our responding both in terms of expectation and responsibility. We can reflect upon it, but we cannot fathom it, let alone theoretically grasp it. At the same time, being called to respond responsibly implies we can make the wrong choice.

\subsection{Summary and conclusion}

Let me try to summarise what my case study so far has achieved for our understanding of freedom, assuming that what I discussed in relation to one specific case applies in a general sense also to the myriad of other possible activities and practices in which we experience freedom or the lack of it. I started with freedom present within a specific practice as the response to a situation. Freedom is made possible by that situation and implies a response to it. Secondly, with the help of the theory of modal aspects I pointed to different elements that can be distinguished within this practice: freedom as connected with human creativity and freedom in dealing with the normative elements of the aspects that are necessarily part of the practice. Then I moved on to the perspective of the first person: the activity of the agent implies freedom. I made the contention that in this activity the different aspects are integrated not just into a unique event, but into a unique act of an agent. At this point the freedom that is involved already escapes scientific analysis, because it is part of the first person perspective and cannot be reduced to the third person perspective of scientific analysis. However, if the deepest level of our freedom and responsibility concerns the relationship between us as creatures to our Creator, there is a second and even stronger reason that human freedom cannot be fully theoretically analysed. Ultimately freedom is a mystery as our being human itself is a mystery. This does not mean we cannot reflect on it, let alone that it completely escapes our experience. It simply means that we cannot fully grasp it by means of theoretical concepts, let alone by the analysis of the special sciences. 


\section{Freedom and science}

\subsection{The nature of the free agent}

In the beginning of this article I referred to the experiments by Libet and Walter. Both experiments seem to prove that there is brain activity related to a conscious decision before the decision itself is made as a conscious act. For some scientists this proves that the decision assumed to be an act of free choice is actually caused by processes within the brain. This, then, would show that free will is an illusion. Libet himself does not draw this conclusion. He assumes that the process of a decision is indeed prepared by the brain, but that our free will still has the possibility to give its consent or interrupt the process. Some critics have argued that the conclusiveness of both experiments is questionable, because they mistakenly assume that the decision of the will can be located in a specific place within the brain (Dennett, 1995:188). The point I want to make is of a different nature.

It seems to me that in both experiments, as in many discussions about the freedom of the will, freedom is understood in terms of a decision made at a specific moment in time while the agent seems to be understood as placed somehow in a control tower where he makes his decision freely and then sends a message to the body or whatever part of it, to perform the action. ${ }^{4}$ I do not deny that in some cases we do indeed make decisions at a specific moment of time. I can now decide to raise my hand instead of continuing to type words on the keyboard of my computer. I have tried to show in the preceding sections that this is not typical for acts of freedom. The decision to raise my hand just for no reason other than showing that I have the possibility to do so is rather rare compared to my active life as a whole in which freedom is manifested. 5 In most cases my free acts are part of a practice and are not isolated events as I tried to argue with my case study of writing a scientific article. Freedom is implied in the overall practice and in my overall conduct, not just located in specific, let alone isolated choices.

$4 \quad$ The latter part is not even necessary if the distinction is made between material and formal freedom. The latter does not include the ability to carry out the decision (Labooy, 2007:146).

5 Even as a supposedly arbitrary act it still has a specific context, because I want to show something. 
Freedom as an essential characteristic of our being human cannot be reduced to decisions at specific moments of time. Just as important, it seems to me, is the fact that the "agent" cannot be located in some special part of myself, like the mind or the soul as the essential substance of the person, let alone in the brain or a specific part of it. It is I, in the unity of my whole being, who is active as the free agent. It is also $I$, as the whole person, that is experiencing freedom, or the lack of it, both in being at home (receptive freedom) within and in responding (creative freedom) to a situation. I am not an "autonomous agent" like a decision maker in a control tower, separate from those parts of my body that are affected by my decisions. I am nothing without my body as I am nothing apart from my development within time and from the relations within which I exist. My freedom is intrinsically connected with the sensory-motor skills that I have acquired, with the education I have received, and with the many people that I have met and related to. Ultimately my freedom depends on the kind of creature that I am as a human being. However, this is not apart from but rather intrinsically connected with being embodied, with having a personal history, and with living in all kinds of relationships. In the concreteness of my being, I act as a free agent, experience freedom and the lack of it. We may study specific elements of these activities, isolate them from the overall practice of which they are a part. We can achieve fascinating knowledge about the way we function as humans in specific respects, for example how brain activities relate to specific experiences and how the latter can be influenced by the former. However, if we do not realise that, apart from the concrete practice with all its complexities, these isolated events loose their meaning and could not even occur; we misunderstand the nature of reality.

What I have tried to show in my analysis of writing a scientific article is that freedom can only be understood as intrinsically connected with our being as a whole. We can analyse specific elements, but freedom in its full sense escapes our conceptual grasp. Freedom is actually as varied as human life itself. It is experienced by the professional tennis player who does not consciously control his moves anymore, because his body and its parts move spontaneously to meet the challenges of the game. It is experienced by the piano soloist who plays the most difficult parts of Beethoven's piano sonata number 29 in B flat major (opus 106 "Das Hammerklavier") without any conscious decisions. In both cases the freedom to perform is based on a long training the result of which the body has "interiorised" and which gives the performer the freedom to be fully him-/herself when he/she in a way loses him-/herself in playing 
either the tennis game or the piano piece. Of course, the absence of conscious decisions does not mean that the player is not fully concentrated. Loss of concentration would lead to an inferior result or even a complete failure.

Another illustration of the experience of freedom would be a concentrated effort to solve a theoretical problem. Here, too, a long training has preceded. Certainly in this case the body is involved too. However, there is a difference. Both the tennis game and the musical performance are bodily activities. Physical descriptions could be given of the movements that produce the intended result, even if the achievement itself cannot be defined by physical laws. The rules of the game are characteristic for the achievement either in terms of tennis or music. In the case of solving a theoretical problem, the activity of thinking cannot be described anymore in physical terms. The activity of thinking is an inner act, certainly not without the function of physical processes within the brain, but not describable in those terms. The bodily functions are only a substrate to the real act. The brain processes are a necessary part of the activity of thought and they are guided by the rules of the thinking act, but the achievement of the thinking process is not the effect of processes within the brain. We do not think with our brains in the same way as we play tennis with our whole body and piano with our arms, hands and fingers.

To summarise this section, what I have tried to show is that the freedom we experience in being a human agent is indeed embodied. The nature of this embodiment differs for different kinds of freedom according to the different abilities (and competencies) that we have, like thinking and playing tennis. In all cases it is important to realise that the body itself cannot be understood in a purely physical or biotic sense. Many kinds of abilities are interiorised within the body as the examples of the tennis player and the musician show. The physical and biotic aspects of our body are opened up by other aspects like the formative and the aesthetic.

\subsection{Causation}

This brings me to the other topic I want to discuss here. The issue of free will is often connected with the possibility of mental causation: the mind having a causal effect on the body, or in more technical terms, mental events having a causal effect on physical events (Murphy, 1998:132 ff.). I cannot discuss all the intricacies that are 
implied here. The basic cause of the problem is either some kind of physicalism or its dualistic alternative. 6 I will limit myself to three remarks in order to show that it is questionable whether the problem of mental causation is actually relevant to the possibility of freedom.

- At several places I have stressed the unity of the activity as a whole, even where different aspects and elements can be distinguished. All human activities in principle function in all the aspects that I mentioned earlier in relation to the theory of modal aspects of reformational philosophy. However, these aspects are not the original elements, let alone events, that only later are combined together in a concrete act. If we analyse these aspects this is only possible by abstracting them from the concrete activity to which they belong. They are not separate physical and mental events that need to be integrated by a causal relation. They certainly are integrated, but this is because they are aspects of one and the same typical activity, not because of a cause and effect relationship between them. The agent is not a mental event or a soul substance, the agent is the concrete person that performs a concrete action. Therefore, as far as a concrete activity is concerned, it is of no use to speak of mental causation as if the mental aspect would have a causal influence on the physical aspect. It is of no use to speak of physical causation in this respect either. Both the "mental event" and the "physical event" are an abstraction from the integrated unity of the concrete act by a concrete agent. 7

- To understand the nature of a causal relationship it is important to distinguish between a causal relationship in the sense of one event causing a change in another event, and a causal relationship in the sense of one event being the cause of the other event in a total sense. In other words, we should distinguish between a physical thing or event causing a change in, e.g. a biotic organism, and a physical thing or event being the cause through which the biotic organism comes into being. Physicalism in one way or another assumes the latter. In this way, however, some

For a critical discussion of physicalism, see Geertsema (2000; 2006).

7 For the understanding of the integration of different aspects within one phenomenon Dooyeweerd's theory of structures of individuality is important. A more complex analysis can be made in terms of an "enkaptic structural whole" which integrates or encapsulates different individuality structures into the unity of one thing. For both, see Dooyeweerd (1957). 
kind of reductionism is unavoidable. What we actually can observe are cases of the first kind of causality. This is true for our common sense experience as well as for specialised research in the field of the neurosciences, and at least for our common sense experience it works both ways. Physical phenomena can affect my thinking and my thinking can affect physical phenomena. As far as I know there is no proof, not even any empirical evidence, that the second kind of causal relationship exists. What we observe is that there are correlations between the physical aspect on the one hand and the emotional, logical and other aspects of specific "mental" phenomena on the other hand. This is, however, no proof that there is a causal relationship between them. It just shows that within a concrete event or experience the different aspects form a unity and (maybe) that one aspect of it cannot be changed without an effect for the event or experience as a whole, including the other aspects.

- We should not confuse the relationship between different aspects of one and the same concrete phenomenon (thing, activity or event) and the relationship between different concrete phenomena. The theoretical explanation for the possibility that phenomena of one kind can have a causal effect on phenomena of another kind is hardly possible when these different phenomena have nothing in common, like the isolated physical and mental events that are often assumed. This is true as much for the "physical event" having a causal effect on the "mental event" as the other way around. When we accept the theory of individual things of reformational philosophy the situation changes dramatically. Essential for this theory is that all things, events, activities, function, at least potentially, in all aspects, only what characterises them is different. It is these concrete phenomena that have a possible causal effect on other concrete phenomena, even if they are of a different kind. Because they function in principle in all the aspects they are not completely different. Functioning within the same aspects, but with a different aspectual qualification, there are all kinds of coherences between them which make the causal relationships possible. We need to distinguish between, on the one hand, the way the different aspects of a concrete phenomenon are integrated into a whole, and on the other hand, the relationship between different phenomena. The latter may be of a causal nature, the first is not. Whether these different phenomena are both internal to the body or one of them external, effecting a bodily process from outside, is not important. My digestive system is also distinct from my thinking. 
The one can affect the other directly or indirectly, but this does not mean that the organic aspect has a causal effect on the logical aspect or the other way around. The causal relationship is between one concrete system and another concrete system, both systems, although of a different kind, having in principle all the different aspects (Geertsema, 2002).

\section{Freedom and human fulfilment}

\subsection{Responsibility and expectation}

In part four above, I elaborated on the relationship between the understanding of freedom and scientific analysis, which I discussed in part three. Now I will look in the other direction, that of worldview or religion. In my first reflection on freedom as response, I contended that our understanding of freedom depends on the way we understand ourselves. Towards the end of the case study I pointed to the biblical understanding of the world as God's creation and introduced the idea of the human person as answering the promisecommand to be both in terms of longing and expectation and of calling and responsibility. It is this point I now want to elaborate on.

To be human means to respond to God's promise-command to be. This applies to both the unity and the diversity of our being. In all aspects of our lives we can discern an element of longing and expectation and of calling and responsibility. These two elements are actually interconnected. On the one hand, our longings and expectations are not just givens. We are responsible for the way we deal with them. Even if we recognise that they are shaped by the direction we have taken in life, by the understanding we have gained of what it means to be human, by the stimuli and incentives that we receive, both from inside and outside, we cannot just take them for granted as we experience them in ourselves and around us. However much they are part of our being human, we have to take responsibility for our longings and expectations, to some extent as to how they have become part of ourselves, but especially as to how we respond to them in the present situation. On the other hand, to be called and to be held responsible, is in itself closely tied with our longings and expectations. It is essential for being human that we are taken seriously, that we are respected and acknowledged for who we are. This implies that we are recognised as capable of carrying out responsible tasks. Of course, sometimes we rather avoid certain responsibilities or try to escape from being held responsible. In a deep sense, however, to be denied any responsibility would mean not to be acknowledged as being fully human. To be called 
upon and being responsible is a deep-seated longing and expectation in our being human.

The second point I want to emphasise is the great diversity both in terms of calling and responsibility and of longing and expectation. In principle these two elements apply to all aspects of our lives. We look for fulfilment in pursuing a career in art, in politics, in business, in sports, in science, et cetera. We look for fulfilment in human relations of marriage, family and friendship. In each case true fulfilment can only occur when the two sides of calling and responsibility and of longing and expectation go together. For a human life in freedom it is not sufficient that our longings and expectations are fulfilled while our calling and responsibility are ignored. If this were the case, my freedom would easily place me over against the freedom of the other. It is the freedom that creates its own home in isolation, at the expense of others. It would amount to the absolutisation of what I called earlier "creative freedom". It misses the experience of freedom as being at home in open relationships with others (receptive freedom), human freedom that requires the recognition of the other for who he/she is. At the same time, if our calling and responsibility is experienced apart from a recognition of our own longings and expectations, there will be no true fulfilment either. We ourselves need to be recognised too, not just the needs of the other. Again, this applies to all aspects of our life. The freedom we can experience in any area depends on being fulfilled as human both in terms of longing and expectation and of calling and responsibility.

\subsection{Frustration and salvation}

The picture of freedom I have sketched so far may seem rather idealistic. It is indeed far from a description of actual reality as if the factual world shows both calling and responsibility and longings and expectations to function in complete harmony. I do, however, claim that the picture I have drawn is true to reality both in the sense that it shows how it could or should be and that it can make us sensitive for what is wrong. Our actual world, according to the biblical picture, is indeed not how it is intended to be. This applies even more to us as humans. Brokenness shows up in all aspects of human life, in all relationships, in our physical and social being, again both in terms of longing and expectation and of calling and responsibility. This brokenness becomes even clearer when we take into account the basic relationship between us as creatures and the Creator. Jesus summarises the intended nature of this relationship with the summary of the law of God in the great commandment, namely to love God 
above all and our neighbours as ourselves (Matt. 22). If we take this commandment also to imply a promise, it relates not only to calling and responsibility, but also to longing and expectation. It indicates the ultimate fulfilment of our being human in both respects. Our actual situation shows how far we are alienated from this fulfilment. Freedom as the possibility to be ourselves as we are meant to be is deeply frustrated. Paul speaks of our being enslaved to sin (Rom. 6) and separated from the life of God (Eph. 4). The biblical picture fully accounts for both the freedom we are intended to experience in our relationship with God and our fellow creatures and how deeply we are fallen away from this destination. Again, both are manifest in all aspects of our life, including the physical. However, the biblical message also points to the way towards liberation. Central to Paul's teaching is that those who believe are free in Christ (Galatians). This new freedom first concerns the new relationship with God, but then it implies the full restoration (and even more) of our original place within the creation (Rom. 8; 1 Cor. 15; Rev. 21 and 22; cf. Gen. 1 and 2).

Both within the teaching of Paul and in the wider experience of humankind, we can find the possibility of an inner freedom in the midst of all kinds of brokenness. For Paul it is the relationship with Christ that makes it possible not to be disturbed anymore by external circumstances (Phil. 4). The Stoa also taught a way through which the inner man would not be troubled by the external conditions of life. Plato even saw the body and its connection with material life as a prison for the soul. There is indeed the possibility of an inner freedom that makes us less vulnerable to outward conditions. However, this inner freedom ought not to make us less sensitive to the suffering of others. In this sense the New Testament does not teach any kind of "apatheia" like the Stoa. Yet, it is crucial for the biblical teaching that freedom in its fullness cannot be limited to an inner experience, even when this is based in the relationship with Christ. The promise of liberation also concerns our bodily existence in its full sense as the hope of the resurrection makes clear. According to the New Testament, the freedom that will be experienced in the new life in the new creation in which heaven and earth are united, will be fully embodied, even in a way we cannot imagine today, as our body too will be transformed (1 Cor. 15; Wright, 2007). We may receive a glimpse of this new embodied freedom when we read the stories about the risen Christ at the end of the Gospels, especially those of Luke and John. 


\section{List of references}

AUSTIN, J.L. 1975. How to do things with words. 2nd ed. Cambridge: Harvard University Press.

BOTHA, M.E. 2007. Metaphor and its moorings: studies in the grounding of metaphorical meaning. Bern: Peter Lang.

DEN BOER, J.A. 2003. Neurofilosofie: hersenen, bewustzijn, vrije wil. Amsterdam: Boom.

DENNETT, D.C. 1995. Het bewustzijn verklaard. Amsterdam: Contact.

DOOYEWEERD, H. 1957. A new critique of theoretical thought. Vol. 3: The structures of individuality of temporal reality. Amsterdam: The Presbyterian \& Reformed Publishing Company.

GEERTSEMA, H.G. 2000. Science and person: beyond the Cartesian paradigm. (In Gregersen, N.H., Görman, U. \& Drees, W.B., eds. Studies in science \& theology. Vol. 7. Aarhus: University of Aarhus. p. 47-64.)

GEERTSEMA, H.G. 2002. Which causality? Whose explanation? Philosophia reformata, 67(2):173-185.

GEERTSEMA, H.G. 2006. Cyborg: myth or reality? Zygon, 41(2):289-328.

GEERTSEMA, H.G. 2008. Knowing within the context of creation. Faith and philosophy, 25(3):237-260.

HEIDEGGER, M. 1997. Inleiding in de metafysica. Nijmegen: SUN.

JOCHEMSEN, H. 2006. Normative practice as an intermediate between theoretical ethics and morality. Philosophia reformata, 71(1):96-112.

LABOOY, G. 2007. Waar geest is, is vrijheid. Amsterdam: Boom.

LIBET, B. 2004. Mind time: the temporal factor in consciousness. Cambridge: Harvard University Press.

MACINTYRE, A. 1981. After virtue. Notre Dame: University of Notre Dame Press.

MORELAND, J.P. \& RAE, S.B. 2000. Body \& soul: human nature \& the crisis of ethics. Downers Grove: InterVarsity.

MURPHY, N. 1998. Nonreductive physicalism: philosophical issues. (In Brown, W.S., Murphey, N. \& Newton, M.H., eds. Whatever happened to the soul? Minneapolis: Fortress. p. 127-148.)

NAGEL, T. 1986. The view from nowhere. New York: Oxford University Press.

SEARLE, J.R. 1969. Speech acts. Cambridge: Cambridge University Press.

VANHOOZER, K.J. 1998. Is there a meaning in this text? Grand Rapids: Zondervan.

WOLTERSTORFF, N. 1995. Divine discourse: philosophical reflections on the claim that God speaks. Cambridge: Cambridge University Press.

WRIGHT, T. 2007. Surprised by hope. London: SPCK.

\section{Key concepts:}

embodiment

freedom

homo respondens

human agent 


\section{Kernbegrippen:}

handelende persoon

homo respondens

lichamelijkheid

vrijheid 
